Original article

Jourow of Shebeed Sutrearly Medict Cullege

Kol. 2, No, 2, Dos. 2010

\title{
EFFECT OF REMIFENTANIL INFUSION ON RECOVERY IN CRANIOTOMY
}

\author{
Md. Zulfiqur Hesan', Md. Rafiqul Islam², ABM. Muksudul Alnan', Abdul Matin ${ }^{4}$ \\ Monwara Begum ${ }^{5}$, Nitai Chandra Serkar ${ }^{6}$, K.M. lqual ${ }^{7}$, Lutful Axiz ${ }^{2}$
}

\begin{abstract}
The primary objective of anesthesia is to facilitate surgery at minimal risk to the patient and to ensure safe optimal recovery following the procedure.

Safe early recovery from craniotomy necessitates an anesthetic technique, pharmacologically adequate to permit early awakening. This study was designed to observe the effect of different pharmacologically active drugs that permit early recovery.

Thirty patients both male and female age ranges from 16 to 60 years having ASA grade I and $I I$ were randomly selected. They were equally divided into two groups. Group I received remifentanil infusion and group II received intermittent intravenous pethidine. Other drug remained same for both group.

Group I Bolus remifentanil $1 \mu \mathrm{g} / \mathrm{kg}$ followed by infusion remifentanil $0.2 \mu \mathrm{g} / \mathrm{kg} / \mathrm{min}$. Induction by thiopental $5 \mathrm{mg} / \mathrm{kg}$ followed by infusion of thiopental $5 \mathrm{mg} / \mathrm{kg} / \mathrm{hr}$. Intubations and neuromuscular block is achieved with pipecuronium. Control ventilation was maintained $66 \%$ $\mathrm{N}_{2} \mathrm{O}$ in oxygen.

In Group II, pethidine intravenously $0.5 \mathrm{mg} / \mathrm{kg}$ before induction and $10 \mathrm{mg} \mathrm{H} / \mathrm{hourly}$ intravenously, Induction by thlopental $5 \mathrm{mg} / \mathrm{kg}$ followed by lnfusion of thlopental $5 \mathrm{mg} / \mathrm{kg} / \mathrm{hr}$. Intubation and neuromuscular block is achieved with pipecuronium. Control ventilation was maintained with $66 \% \mathrm{~N}_{2} \mathrm{O}$ in oxygen.

Anesthetic procedure was performed with monitoring of hemodynamic variables heart rate, blood pressure, $\mathrm{SPO}_{2}, \mathrm{ETCO}_{2}$, temperature, urine output. Data were analyzed by using unpaired ' $t$ ' test and Mann-Whitney-U test.

Recovery was evaluated using standardized end point. Time to spontaneous respiration, extubation, response to verbal command where significantly $(P=0.001)$ earlier with remifentanil than pethidine. Discharge from recovery room were earlier in group I ( $P=0.015)$.
\end{abstract}

\section{Introduction}

The primary objective of anesthesia is to facilitate surgery at minimal risk to the patient and to ensure optimal recovery following the procedure.

Recovery from anesthesia must occur predictably and safely

1. Astistent Prolessor Anaesthesiology Shutreed Sturawardy Medical College and Hospital, Dbaka

2. Associate Professor Pediacrics, Stabeed Stunkwardy Medical College and Hospitsi, Dhaks.

3. Principal Staheed Sharawarty Medical College and Hospilsi, Dhaka.

4. Astisant Professor, Pediatrics, Shaheed Shurawerdy Medical College and Hospical,Dhankn

S. Setior consaliant Gynaecology \& Obs, Apollo Hospital Dhake.

6. Assistant Prolessor, Anvestheriology Stasbeed Shuruwerdy Medical College and Hospital, Dhake.

7. Setior consaltanl Anaesteresiology, Apollo Hospital Dhake.

8. Consultant Anaesthesiology, Apollo Hospitul Dhake.

\section{Cotrespondesce}

Di. Md. Zulfiqqar Hesan MBBS. MD.

Ansistaol Professor, Anestbetiology

Shaheed Stownwardy Medical College and Hospital, Dhata. and with minimal pain and any post operative sequali must be minimized. These objectives are achieved using balanced anesthesia with a combination of hypnotics, analgesics and neuromuscular blocking agents. Opioids are widely used as the analgesic component of balanced techoique. Optimal dosing with traditional opioid is associated with adverse effect and delayed post operative recovery with risk of recurrent respiratory depression resulting from accumulation and redistribution of this drugs within the body ${ }^{123}$.

Prolonged recovery of the respiratory function at the end of the operation due to accumulation of opioids may delay extubation and an opioid antagonist may be needed. This is getting importance with growing practice of daycare surgery when residual effect of all anesthetics are of concern because patients arc discharges home in an unmonitored environment. In neurosurgical anesthesia prolonged administration of opioid may cause prolonged recovery of respiratory function.

Recurrent or delayed respiratory depression is potentially life threatening and necessitate careful post operative monitoring of patients together with ventilatory support following the use of high dose opioid anaesthesia. Respiratory depression represents a particular problem in patient with renal or hepatic insufficiency who have a reduced ability to 
metabolize and excrete the traditional opioids and are thus at increased risk of drug accumulation ${ }^{4,5}$. Recurrent respiratory depression after bolus administration of fentanyl has been associated with secondary peak in plasma level. It has also been reported with alfentanil, sufentanil and petbidine. Recurrent respiratory depression may cause rapid oxygen desaturation and may be fatal in an unmonitored setting.

Remifentanil hydroehloride is a potent esterase metabolized $\mu$-opioid receptor agonist that bas been specifically developed to fulfill some of the unmet needs of anesthesia. A systematic development programme has produced a short acting drug with rapid onset and offset of action. This allows for ease of titration to respond quickly to changes in intraoperative anesthetic requirement and also permits optimal dosing without the risk of accumulation and subsequent adverse effect. The rapid predictable offset of action of remifentanil is the result of its metabolism in the blood and tissues by nonspecifie esterases.

Another important clinical benefit arising from the esterase metabolism of remifentanil is that recovery is predictably rapid across all patient groups irrespective of the duration of exposure. In addition, dose reduetion is unneeessary in patients with impaired renal or hepatic function. The pharmacokinetic characteristics of remifentanil contrast markedly with those of other currently available traditional opioids which, when administered at optimal anesthetic dose may be assoeiated with problems cause by their prolonged duration of action and delayed recovery resulting from their accumulation and redistribution within the body. Thus remifentanil offers a number of elinical advantages compared with traditional opioids.

Pethidine is available, less costly and conventionally used as analgesia for balanced anesthetic technique in intracranial surgery. Pethidine however is not a drug of choice in intracaneal surgery in moders technique of anesthesia as it is associated with adverse event and delayed postoperative recovery from accumulation and redistribution of drug within the body',

Major goal of intracranial surgery is to maintain hemodynamic stability and normal ICP. Quite recovery without residual effect of anesthesia is required after intracranial surgery. Sustained analgesia desirable in intracranial surgery provided by continuous infusion of remifentanil cannot be achieved by intermittent intravenous pethidine. Pethidine currently used in our country has a low recovery score. Remifentanil sbould bave even bigber.

\section{Subjeets and Methods}

This analytical type of observational study was carried out in the department of Anestbesia, Analgesia and Intensive care medicine of Bangabandhu Sheikh Mujib Medical University, Dhaka from July 1998 to December 1999. Thirty eases with different neurosurgical problem witb intracranial space occupying lesion for craniotomy under general anesthesia were selected for the study. Both male and female patient within age group 16-60 yrs were selected. They were recruited and grouped randomly. The purpose of the study, methodology, complications, and side effects of eacb method of anesthesia were clearly explained to eacb of the subject and recruited only after they had given written consent. The approval of the Ethical Commitree of Bangabandhu Sheikh Mujib Medical University, Dhaka was duly taken before carrying out the study.

\section{Grouping of patients and drug treatment}

Group 1 Remifentanil + Thiopental + pipecuronium.

Group II Pethidine + Thiopental + pipeeuronium.

\section{Procedure}

\section{Preoperative Management}

Preanesthetic assessment was done before surgery, Preoperative medication that produces sedation or ventilatory depression was avoided in the patient with intracranial tumor.

\section{Intraoperative Management}

Group 1 patients received an injection of remifentanil $1 \mu$ $\mathrm{g} / \mathrm{kg} / \mathrm{IV}$ over 30 seconds followed by an infusion of remifentanil $0.2 \mu \mathrm{g} / \mathrm{kg} / \mathrm{min}$.

Group II patients receive injection of pethidine $0.5 \mathrm{mg} / \mathrm{kg} / \mathrm{iv}$ followed by $10-15 \mathrm{mg}$ I. $V$ half hourly.

In both groups induction of anesthesia was performed by thiopental sodium $5 \mathrm{mg} / \mathrm{kg} / \mathrm{TV}$ in 30 seconds followed by infusion of thiopental $5 \mathrm{mg} / \mathrm{kg} / \mathrm{hr}$. Patient was hyperventilated during the performance of induction. Patient was intubated with nondepolazing muscle relaxant pipecuronium $0.1 \mathrm{mg} / \mathrm{kg}$ and control ventilation was maintained with $1 / 4$ of intubating dose balf hourly.

In both groups ventilation was maintained with $\mathrm{N}_{2} \mathrm{O} / \mathrm{O}_{2}$ at ratio 66:33 and ventilation was adjusted to provide $\mathrm{ETCO}_{2}$ $30 \mathrm{mmHg}$.

Intraoperative fluid was maintained with Hartman solution. Intravascular fluid volume depletion due to blood loss was corrected with the whole blood.

Intraoperatively increased intracranical pressure was treated with mannitol 0.5 to $0.75 \mathrm{gm} / \mathrm{kg} / \mathrm{IV}$, intravenous thiopental, increasing the infusion dose of remifentanil, mild hyperventilation, normovolemia, adequate head up position, free venous drainage; no compression of the juglar vein.

Incidence of bradycardia $<40 / \mathrm{min}$, tachycardia $>90 / \mathrm{min}$, hypotension MAP $<65 \mathrm{mmHg}$, hypertension $>90 \mathrm{mmHg}$ were controlled by adjustment of remifentanil and thiopental infusion and by use of atropine ephedrine and intravenous fluid.

Thiopental infusion was discontinued after dural closer. Remifentanil infusion was discontinued at the head bandage and $\mathrm{NO}_{2}$ administration was also discontinued. Oxygenation was maintained by intermittent positive pressure ventilation with $100 \%$ oxygen until the return of spontaneous respiration. On returning of spontaneous respiration residual neuromuscular block was reversed with neostigmine 0.08 $\mathrm{mg} / \mathrm{kg}$ and dose of atropine $0.02 \mathrm{mg}$ per $\mathrm{mg}$ neostigmine. After resumption adequate respiration the trachea was 
extubated and time for verbal command was noted.

Recovery from anesthesia was assessed using a standardized end point including time to spontaneous respiration, time to extubation, respond to verbal command and eligibility for discharge from recovery room. Discharged from recovery room was assessed by Aldrete Score 10.

\section{Statistical Analysis}

All statistical analyses were performed by using SPSS for windows. Data are presented as Mean + SD. Unpaired t-test and Mann-Whitney-U test were used to compare the difference between two groups. $\mathrm{P}<0.05$ was considered as the level of significance.

\section{Results}

Demographic characteristics of patients

The age, sex and weight are presented in table I. The median age was 35 ycars \& range was $18-55$ in years in group I and

Table-I: Age sex and waìgihtp distripution ofithup Istudy

\begin{tabular}{l|l|l}
\hline s\$biscfsatients & 15 & 15 \\
\hline Sex (Male/Female) & $12 / 3$ & $11 / 4$ \\
\hline Age, Median (range), year & $35(18-55)$ & $30(20-50)$ \\
\hline Weight, Mean $=$ SD, Kg & $50 \pm 12$ & $54 \pm 18$
\end{tabular}

median age 30 years \& range was 20-50 in years in group II. The weight (mean $+\mathrm{SD}$ ) were $50+12 \mathrm{~kg}$ in group I and $54+$ $18 \mathrm{~kg}$ in group II. Age and weight are almost similar in two groups.

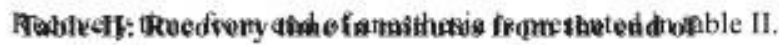
anesthesia

\begin{tabular}{|l|c|c|c|}
\hline \multicolumn{1}{|c|}{ Parameters } & $\begin{array}{c}\text { Group I Median } \\
\text { (range) time in } \\
\text { minutes }\end{array}$ & $\begin{array}{c}\text { Group II } \\
\text { Median (range) } \\
\text { time in minutes }\end{array}$ & $\begin{array}{c}\text { Group I vs } \\
\text { Group II } \\
\text { p value }\end{array}$ \\
\hline $\begin{array}{l}\text { Time to } \\
\text { spontaneous } \\
\text { respiratory rate }\end{array}$ & $\begin{array}{c}9 \\
(5-15)\end{array}$ & $\begin{array}{c}18 \\
(12-25)\end{array}$ & $0.001^{* * *}$ \\
\hline $\begin{array}{l}\text { Time to tracheal } \\
\text { extubation }\end{array}$ & $\begin{array}{c}14 \\
(9-20)\end{array}$ & $\begin{array}{c}24 \\
(15-34)\end{array}$ & $0.001^{* * *}$ \\
\hline $\begin{array}{l}\text { Time to fesponse } \\
\text { to verbal command }\end{array}$ & $\begin{array}{c}19 \\
(15-25)\end{array}$ & $\begin{array}{c}30 \\
(20-55)\end{array}$ & $0.001^{* * *}$ \\
\hline $\begin{array}{l}\text { Discharge from } \\
\text { recovery room } \\
\text { command }\end{array}$ & $\begin{array}{c}18 \\
(56-150)\end{array}$ & $0.015 * * *$ \\
\hline
\end{tabular}

Data are presented as Median (range). Mann-Whitney-U test was one as the test of significance.

$* * 0<0,001$

Time to spontaneous respiratory rate in group I was median (range) $9(5-15) \mathrm{min}$ and $18(12-25) \mathrm{min}$ in group II. In group I recovery time was significantly $(\mathrm{P}=0,001)$ less than group II.
Similarly time to tracheal extubation and verbal command in minute were significantly less in group I compare to group 11 [group I vs group II, extubation: $14(9-20)$ vs $24(15-34)$, $(\mathrm{P}=0.001)$, verbal command: $19(15-25)$ vs $30(20-55)$, $(\mathrm{P}=0.001) 1$,

Discharge from recovery room was earlier in group I compared to group II, [103(55-150) vs $155(90-210) \mathrm{min}$, $(\mathrm{P}=0.015)]$.

\section{Discussion}

Anesthesia the gate way to surgery, its successful exit end with safe recovery. Recovery from anesthesia has respiratory, cardiovascular, metabolic, endocrine and neurologic consequence ${ }^{6}$. Ideally patient recovery from neurosurgery should emerge rapidly from anesthesia to permit immediate assessment of the result of surgery and to provide baseline for continuing postoperative neurologic follow up?

Recovery was assessed using standardized end point including time to spontaneous respiration, extubation, response to verbal command and eligibility for discharge from recovery room.

Time to spontaneous respiration earlier in remifentanil than pethidine. Return of respiration was smooth than pethidine. Time to adequate spontaneous respiratory rate followed by extubation was carlier with remifentanil. Respond to verbal command was also earlier with remifentanil. Psychomotor and psychometric function better with remifentanil than pethidine. Quality and speed of recovery was better with remifentanil. Recovery with remifentanil statistically significant than pethidine.

In a study done by Cartwright et al., 1997 remifentanil was compared with alfentanil as part of balanced anesthesia with $0.8 \%$ isoflurane in both group. Remifentanil patients response significantly with better recovery of psychomotor and psychometric function. Recovery was earlier and better with remifentanil. Present study used thiopental. Thiopental produce dose dependent reduction in $\mathrm{CBF}, \mathrm{CMR} 02$ and $1 \mathrm{CP}$. Thiopental attenuates cerebal vasdilation produced by $\mathrm{N}_{2} \mathrm{O}$.

A comparison study of elective craniotomy between remifentanil and alfentanil done by Sneyed et al. ${ }^{\mathrm{s}}$. Bolus injection of remifentanil $\mathrm{I} \mu \mathrm{g} / \mathrm{kg}$ followed by infusion of remifentanil $0.5 \mu \mathrm{g} / \mathrm{kg} / \mathrm{min}$ in one group. Bolus followed by infusion of alfentanil in other group. Alfentanil followed by remifentanil in another group. Propofol was used for induction \& maintenance. Lungs were ventilated with $66 \%$ $\mathrm{N}_{2} \mathrm{O}$ in $\mathrm{O}_{2}$. Median times to tracheal extubation and obey commands were similar in all groups. The process of recovery was qualitatively different with remifentanil group with patient emerging suddenly with near synchronous return of respiration, tracheal extubation \& responses to command.

\section{Conclusion}

Early recovery a major goal of intracranial surgery anesthesia is achieved by remifentanil. Though costly its unique clinical advantage make it superior to pethidine. 


\section{Reference:}

1. Becker LD,Poulson BA,Miller RD. Biphasic respiratory depression after feotanyl- droperidol or feotanyl alone used to supplemeot nitrous oxide anestbesia. Anestbesiology 1976;44;PP291-6.

2. Chang J. Fish KJ.Acute respintory arrest and rigidity after anestbesia witb sufeotanil; Acese report. Aaesthesiology 1985;63;PP710-11.

3. Mabla ME, white SE, Moneta MD. Delayed respiratory depression after alferotanil. Anesthesiology 1988; 69, PP 593-5

4. Physicina's Desk Reference, 48th edition. Medical economics Deta Production Company, NJ, 1994:P1081 - 103.

5. Stabski DR, Shafer SI. Quantifying enestbetic drugs interection. Implicetion for drug dosing, Anesthesiology 1995; 83: P 159 -66.
7. Bracco D, Ravussin P,gtoadetur JM. Eerly awakening or long term sedation 6. Murzi DA, Black S, Lastsso T. Labetsiol and esmolol in the control of byperteasion eflet intrucrenial surgery. Anesth Analg 1990; 68; P70-after netro-anegthesia Eut Anestberiology $1998 ; 28 ; 815$.

8. Sneyd JR, Whaley A, Dimpel HL and Andress CJH.An open rundomized comparison of afentaail, remifeataail and alfentanil and alfentanil followed by remifentaail in asesthesia for craniolomy.Bribish Journal Anesthesia 1998;81;PP361-364. 